\title{
Małgorzata Eyzińska
}

97-400 Bełchatów

Osiedle Żołnierzy POW 5

mlyzinska@wp.pl

\section{WYKORZYSTANIE TURYSTYCZNE „SPORT HOTELU” W BEECHATOWIE W 2003 R.}

\section{TOURIST UTILIZATION OF THE SPORT HOTEL IN BEŁCHATÓW IN 2003}

\section{WSTEP}

Bełchatów położony jest w środkowopołudniowej części województwa łódzkiego, nad rzeką Rakówka, w odległości $23 \mathrm{~km}$ na zachód od Piotrkowa Trybunalskiego i $50 \mathrm{~km}$ na południe od Lodzi. Przez Bełchatów przebiega również droga $\mathrm{nr} 8$ o znaczeniu międzynarodowym, łącząca Warszawę, przez Wrocław, z Praga. Wedlug danych z 2004 r., Belchatów liczy 64692 mieszkańców zameldowanych na pobyt stały i czasowy, w tym 32719 kobiet i 31973 mężczyzn. Największymi pracodawcami dla mieszkańców Bełchatowa są: Kopalnia Węgla Brunatnego „Bełchatów” SA, która zatrudnia 9316 osób, oraz Elektrownia „Belchatów" zatrudniająca 4900 osób, a wraz ze spólkami 5600 (dane z lutego 2004 r.). Obok terenów kopalnianych, w bełchatowsko-kleszczowskiej strefie uprzemyslowionej mieści się obszar rogowieckiego punktu przemysłowego, który stawia region bełchatowski w roli bardzo atrakcyjnego partnera gospodarczego (LISZEWSKI 1985). Miasto ma dobre warunki dla lokalizacji nowych przedsiębiorstw oraz duże rezerwy terenów i powierzchni przemysłowych. W związku z powyższym baza noclegowa w Bełchatowie nastawiona jest na przyjęcie i obsługę gości indywidualnych podróżujących służbowo, klientów konferencji zarówno pobytowych, jak i miejscowych, grup turystycznych oraz uczestników bankietów i innych imprez gastronomicznych. „Sport Hotel” w Bełchatowie ${ }^{1}$ jest obiektem trzygwiazdkowym, funkcjonującym od 18 XI 1994 r. Na początku lat 90. „Sport Hotel” znajdował się $W$ strukturach organizacyjnych

\section{INTRODUCTION}

Belchatow is situated in the central and southern part of Lódź Województwo on the River Rakówka, $23 \mathrm{~km}$ west of Piotrków Trybunalski and $50 \mathrm{~km}$ south of Łódz. The international route $\mathrm{E} 8$, joining Warsaw with Prague through Wroclaw, runs through Bełchatow. According to data from 2004, Bełchatów has 64,692 inhabitants - 32,719 female and 31,973 male. The biggest employers are the Belchatow S.A. lignite mine (KWB Bełchatow S.A.) which employs 9316, and the Belchatow Power Station which employs 4900 (including associated companies the number reaches 5600 - figures from Feb 2004). Apart from the mining areas, the Bełchatow-Kleszczow industrial zone includes the Rogow industrial area making the whole region a very attractive business partner (LISZEWSKI 1985). The town offers good conditions for establishing new enterprises, as well as large reserves of industrial land. Therefore, the hotel infrastructure in Bełchatow is oriented towards individual guests travelling for business, conference participants - visiting and local, tourist groups, special banquet guests and for other events.

The Sport Hotel in Bełchatów ${ }^{1}$ is a three-star hotel opened on $18^{\text {th }}$ 
Przedsiębiorstwa Państwowego KWB „Bełchatów" SA, a 1 V 1999 r. przekształcony zostal W spólkę prawa handlowego, tj. spółkę $\mathrm{z}$ ograniczoną odpowiedzialnością, której wszystkie udziały do dnia przeprowadzania badań należaly do KWB „Belchatów” SA. Obiekt zlokalizowany został zgodnie z planem miejscowym w „strefie śródmiejskiej i mieszkaniowo-usługowej" Bełchatowa. Lokalizacja „Sport Hotelu” jest atrakcyjna ze względu na jego usytuowanie w centralnej części miasta, a także ze względu na to, że znajduje się w odległości $21 \mathrm{~km}$ od trasy szybkiego ruchu Warszawa-Katowice. Dodatkowym atutem lokalizacji hotelu jest fakt, że mieści się w zespole obiektów rekreacyjnych. W bezpośrednim sąsiedztwie umiejscowiona jest plywalnia kryta oraz basen na wolnym powietrzu. Po drugiej stronie ulicy znajduje się stadion GKS „Bełchatów”.

Informacje potrzebne do analiz autorka uzyskala metodą badań terenowych, podczas których użyto takich technik, jak kwestionariusz ankiety, karta inwentaryzacyjna oraz wywiad swobodny. Ankiety przeznaczone byly dla gości przebywających w hotelu w okresie od $1 \mathrm{~V}$ do 12 XII $2003 \mathrm{r}$. i rozłożone były $\mathrm{w}$ pokojach hotelowych wraz $\mathrm{z}$ materiałami informacyjnymi (dostępne byly w trzech językach: polskim, angielskim i niemieckim), dzięki czemu pozyskano opinie zarówno gości krajowych, jak i zagranicznych. W ciągu siedmiu miesięcy zebrano 205 ankiet, co stanowi 53,1\% ogółu rozprowadzonych kwestionariuszy ankietowych, w tym 170 polskich, 20 angielskich i 15 niemieckich. Celem przeprowadzonej ankiety było pozyskanie informacji dotyczących charakteru przyjazdu gości, jakości usług świadczonych przez hotel oraz danych społeczno-demograficznych gości hotelowych. Dane z karty inwentaryzacyjnej, którą autorka przeprowadziła w hotelu, stanowią opis głównie materialnej części hotelu, czyli wyposażenia pokoi i całego obiektu. Udzielone odpowiedzi na pytania zawarte w karcie inwentaryzacyjnej dostarczyły informacji dotyczących formy własności, roku rozpoczęcia działalności, zajmowanej powierzchni, kategorii hotelu, jak również jego lokalizacji, otoczenia, usług dodatkowych. Wywiad swobodny przeprowadzony został $\mathrm{z}$ pracownikami hotelu oraz z pracownikami instytucji państwowych, takich jak Urząd Miasta oraz Starostwo Powiatowe w Bełchatowie. Materiały uzyskane drogą wywiadu umożliwiły pogłębienie analizy jakościowej badanego zjawiska. Bardzo ważnym i wiarygodnym dla pracy materiałem źródłowym były także wydruki z programu komputerowego „Brilliant” sto-
November 1994. In the early 1990s it was part of the KWB Belchatów S.A. State Enterprise, and on $1^{\text {st }}$ May 1999 it was transformed into a limited liability company whose shares were all owned by the KWB Belchatow S.A. (the information concerns a period prior to the study). The hotel was built according to the local plan in the 'central, residential and service zone' of Belchatow. This is attractive due to its centrality, in addition to being just $21 \mathrm{~km}$ from the Warsaw-Katowice route. An additional asset is that it was built next to recreation facilities (indoor and out-door swimming pools, and the GKS Belchatow stadium).

The information required for the analysis was obtained during a field study using tools such as a survey questionnaire, an 'inventory' and open interviews. The questionnaires were for guests staying at the hotel between $1^{\text {st }}$ May and $12^{\text {th }}$ December 2003, and they were left in hotel rooms along with information available in three languages: Polish, English and German. In this way opinions were gathered from both Polish and foreign guests. Within seven months 205 questionnaires had been collected, $53.1 \%$ of all copies distributed and included 170 replies in Polish, 20 in English and 15 in German. The aim of the survey was to obtain information regarding the nature of the stay and the quality of service, as well as a socio-demographic profile of the hotel guests. Data from the 'inventory' which the author used is mainly descriptive i.e. the furnishing of rooms and the whole building, and also provided information about the form of ownership, the year the hotel was opened, its total area, its category, as well as its location, surroundings and additional services.

The open interviews were carried out among the employees and some state institutions such as the town council and the Starostwo Powiatowe (the local authority) in Bełchatow. The materials obtained in this way enabled the author to make a more detailed 
sowanego w dziale recepcji „Sport Hotelu”, obejmujące okres od 1 VIII 2002 r. do 28 X 2003 r. Na podstawie tej dokumentacji autorka dokonala charakterystyki oddzielnej dla firm i osób indywidualnie przyjeżdżających do hotelu. Wszystkich odwiedzających w tym czasie obiekt było 5533. Najliczniejszą grupę gości stanowili klienci zbiorowi - 4530 osób ( $82 \%$ ogółu gości) z 417 firm, które wspólpracowaly ze „Sport Hotelem” na przełomie 2002 i 2003 r., natomiast osób korzystających $\mathrm{z}$ usług hotelu indywidualnie było 1003. Wykorzystywanie w charakterystykach jedynie podziału na gości z firm i indywidualnie odwiedzających hotel wynikał z braku danych dotyczących osób przybywających w grupach, ponieważ w momencie meldowania nie mają one obowiązku podawania swojego adresu zamieszkania. W przypadku zarejestrowanych firm nie było możliwe scharakteryzowanie gości z siedmiu $\mathrm{z}$ nich $\mathrm{z}$ powodu braku danych. Informacje zawarte na wydrukach pozwoliły na określenie liczby osób korzystających z noclegów, liczby udzielonych noclegów, przeciętnego czasu pobytu w obiekcie, średniego wykorzystania i sezonowości hotelu oraz nazwy miejscowości stałego zamieszkania gości². Wymienione badania stanowią wystarczająco wiarygodną podstawę do wykazania efektywności działalności „,Sport Hotelu”, określenia zasięgu przestrzennego ruchu turystycznego, a także przeanalizowania danych społeczno-demograficznych klientów korzystających z noclegów.

\section{WYNIKI BADAŃ}

Bardzo duże znaczenie dla ekonomiki przedsiębiorstw turystycznych, jak pisze RAPACZ (1994), ma prawidłowa eksploatacja obiektów i urządzeń jego zaplecza noclegowego. Uważa on, że o wielkości wykorzystania obiektu świadczy m.in. liczba miejsc noclegowych, która wyraża jednocześnie jego potencjal uslugowy. „Sport Hotel” posiada 100 miejsc noclegowych w 52 jednostkach mieszkalnych, co daje w ciagu roku 36500 miejsc noclegowych. Całoroczne świadczenie usług noclegowych w zakładach hotelarskich jest charakterystyczne dla hoteli kongresowych. Wskaźnik wykorzystania miejsc noclegowych w badanym obiekcie w 2003 r. wyniósł niespełna 18\%. Przy zdolności usługowej wynoszącej 36500 miejsc noclegowych zarejestrowano sprzedaż 6551. Badania przedstawione w niniejszym artykule obejmują przełom lat qualitative analysis. The printouts of the 'Brilliant' computer system used at the Sport Hotel reception were very important and reliable sources of information covering the period $1^{\text {st }}$ August $2002-28^{\text {th }}$ October 2003 which enabled the author to prepare two separate descriptions: one of the companies, and the other of the individual guests staying at the hotel. The total number of visitors during that time was 5533 of which the most numerous were group guests (4530 $82 \%$ ) from the 417 companies making use of the Sport Hotel in 2003, while the number of individual guests was 1003. Dividing the guests into only two groups (company and individual) resulted from a lack of data on groups as those guests are not obliged to give their addresses at the check-in. Guests from seven of the groups could not be described due to this lack of personal data. The information included in the printouts allowed the author to establish the number of people staying at the hotel, the number of beds sold, the average length of stay, the average and seasonal utilisation of the hotel, as well as the guests' home location ${ }^{2}$. The research described is sufficiently reliable to show the success of the Sport Hotel, establish its tourist spatial range, as well as to analyse sociodemographic data regarding the hotel guests.

\section{RESEARCH RESULTS}

According to RAPACZ (1994), tourism enterprise economics largely depend on the appropriate utilisation of a hotel's infrastructure. He believes that hotel utilisation is reflected in the number of beds, which at the same time shows its service potential. The Sport Hotel offers 100 beds in 52 rooms which amounts to 36,500 beds a year, and the service it provides all year round is typical of conference hotels. Bed take up in the hotel in 2003 was below 18\% 
2002 i 2003. W celu pelniejszego zilustrowania przedstawionych tu zjawisk odniesiono je do 1999 r., który był jednym z najlepszych okresów w dzialalności hotelu. W 1999 r. wykorzystanie pokoi w „Sport Hotelu” kształtowało się na poziomie $39,2 \%$, a w 2003 r. wynosilo niespelna $25 \%$ ich zdolności noclegowych. Wedlug TURKOWSKIEGO (1993), poziom wykorzystania obiektów turystycznej bazy noclegowej w dużym stopniu uzależniony jest także od długości i sezonowości pobytów gości. W analizowanych latach poziom wykorzystania pokoi w poszczególnych miesiącach jest podobny. Największe wykorzystanie obiektu zanotowano w 1999 r.: w październiku - 57\%, a najmniejsze w lipcu - 20,3\%. Dla porównania, w analogicznych okresach roku 2003 wskaźniki te wynosiły odpowiednio: 20,2 i 8,9\% (rys. 1). W sytuacji, w której wykorzystanie miejsc hotelowych w Polsce wynosi średnio 60-70\% (TURKOWSKI 1993), widać jak niskie było obłożenie badanego obiektu w przedstawionych latach.

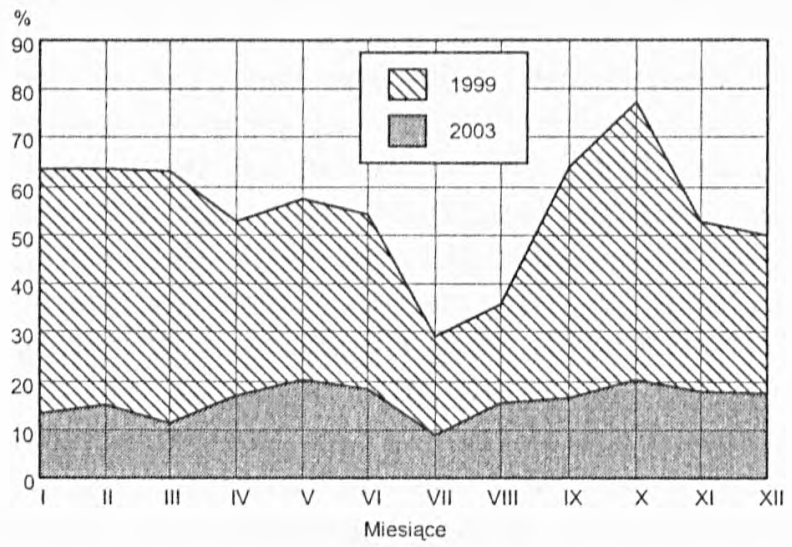

Rys. 1. Procentowy wskaźnik wykorzystania pokoi w "Sport Hotelu” w Bełchatowie w roku 1999 i 2003

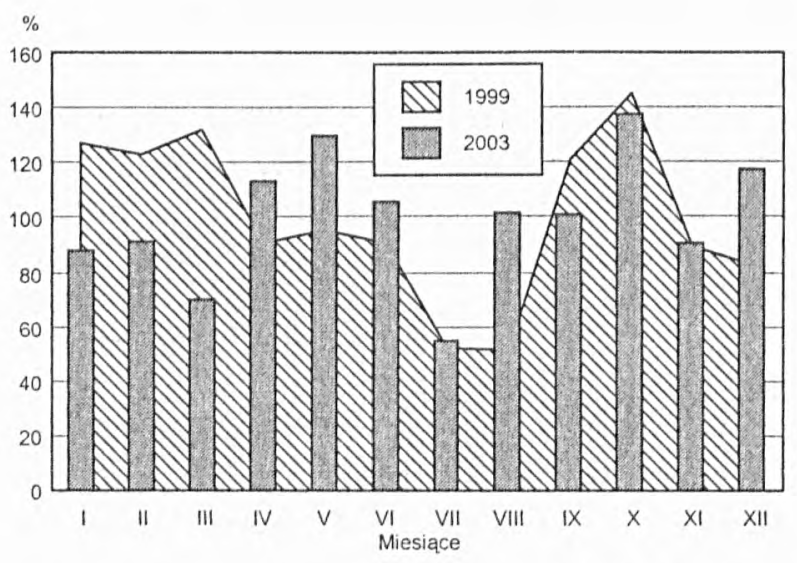

Rys. 2. Współczynniki sezonowości w "Sport Hotelu" w Bełchatowie w roku 1999 i 2003 and given its capacity of 36,500 , only 6551 were therefore sold. Research presented in this article covers 2003 and in order to illustrate in more detail this was compared with 1999, one of the most prosperous periods at the hotel. In 1999 room take-up reached 39.2\%, while in 2003 it was below $25 \%$. According to TURKOWSKI (1993), hotel utilisation also depends on the length and seasonality of stays. In these two years room take-up in individual months was similar. In 1999 the highest $(57 \%)$ was recorded in October and the lowest $(20.3 \%)$ in July - for comparison, in the corresponding months of 2003, the figures were $20.22 \%$ and $8.9 \%$, respectively (fig. 1). In a situation when the average hotel take-up is 60-70\% (TURKOWSKI 1994), it becomes clear how low it was in both those two years.

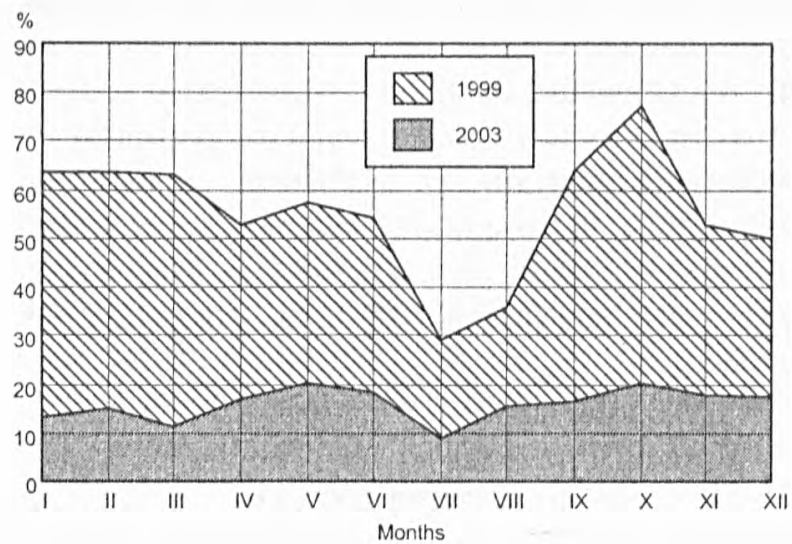

Fig. 1. Room take-up percentages at the Sport Hotel in Bełchatów in 1999 and 2003

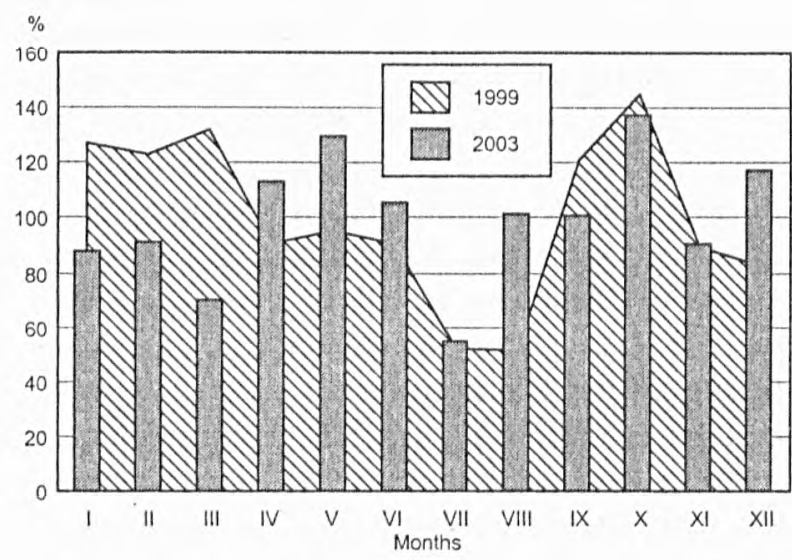

Fig. 2. Seasonality at the Sport Hotel in Bełchatów in 1999 and 2003 
Wskaźnik przeciętnej długości pobytu gości określa czas korzystania z noclegów w danym obiekcie przez statystycznego turystę. Przeciętny czas pobytu gości w "Sport Hotelu” wynosil od 1,23 do 1,8 dnia. W badanym okresie nie odnotowano dużego zróżnicowania przeciętnego czasu pobytu gości w poszczególnych miesiącach. Najkrócej przebywano w grudniu, natomiast we wrześniu wskaźnik ten osiągnąl największą wartość. Przeciętna długość pobytu gościa hotelowego wynosiła 1,57 dnia. Wyklucza to turystyke pobytową (powyżej siedmiu dni) i wycieczkową (powyżej dwóch dni). Popyt na usługi hotelarskie jest nierównomierny, wynikiem czego jest zjawisko sezonowości. Analiza ruchu turystycznego w "Sport Hotelu” wskazuje także na różne natężenie ruchu turystycznego w ciągu tygodnia. Goście najliczniej przebywali w obiekcie w poniedziałek, środę i czwartek stanowi to ogółem $57,9 \%$ wszystkich nocujących w hotelu. Wahanie popytu w ciagu tygodnia wskazuje na zdecydowanie mniejsze wykorzystanie pokoi z piątku na sobotę i z soboty na niedzielę. Odnotowano wówczas obecność zaledwie 10,2\% ogóhu turystów w stosunku do miejsc noclegowych. Wyraźna jest tendencja spadkowa - im bliżej weekendu, tym mniejszy ruch turystyczny w hotelu. Zachowanie takie wskazuje jednoznacznie na występowanie turystyki biznesowej oraz kongresowej. Wykorzystanie potencjału usługowego „Sport Hotelu” jest typowo sezonowe. Sezonem dla hotelu jest okres od września do czerwca, a lipiec i sierpień jest okresem pozasezonowym. Najwyższa frekwencja klientów widoczna była w październiku i w maju. Wskaźnik sezonowości ksztaltował się w tym czasie na poziomie $128,8 \%$ oraz $128,4 \%$. Najsłabsze wykorzystanie hotelu zarejestrowano w lipcu, w którym wskaźnik sezonowości wyniósł 55\% (rys. 2). Współczynniki sezonowości za lata 1999 i 2003 wykazują zbieżność ze wskaźnikami wykorzystania pokoi hotelowych. Z wykresu (rys. 2) odczytać można, że zgodnie $\mathrm{z}$ podstawową funkcją szkoleniowo-konferencyjną pełnioną przez obiekt, jego wykorzystanie zdecydowanie rośnie i maleje w charakterystycznych dla tego typu obiektów okresach. Rok 2003 wyraźnie zaznaczył się zwiększonym ruchem turystycznym: od kwietnia do czerwca oraz w październiku i grudniu (rys. 2). W tych miesiącach współczynnik sezonowości wyraźnie przekroczył średnią równą 100 . Wysoki współczynnik sezonowości $\mathrm{w}$ grudniu związany był $\mathrm{z}$ imprezami organizowanymi przez KWB Bełchatów SA, takimi jak Barbórka czy Karczma Piwna i Comber Babski. Spadek sezonowości natomiast wyraźnie zaznaczył się w lip-
The average length of stay is defined by the time a 'statistical' tourist spends at the hotel: at the Sport Hotel this lasted 1.23-1.8 days. At the time of the study the author did not observe any serious differentiation in individual months: shortest in December and longest in September, with an average of 1.57 days. This figure excludes longer stays (over seven days), as well as excursions (more than two days). The demand for hotel services varies resulting in seasonality. The analysis also points to a differing intensities during the week with the largest number on Mondays, Wednesdays and Thursdays (57.9\%). The changing demand throughout the week pointing to a considerably lower room take-up on Friday and Saturday nights - only $10.2 \%$ in relation to the number of beds available. A clear decreasing trend could be observed - the closer to the weekend, the smaller the tourist activity. This clearly indicates business and conference tourism. The utilisation of potential services is typically seasonal lasting from September to June, with July and August an out-of-season period. The majority come in October and May when the level of seasonality reached $128.8 \%$ and $128.4 \%$. The lowest utilisation was registered in July, with a seasonality figure of $55 \%$ (fig. 2). The seasonality indicators for 1999 and 2003 correspond to room take-up indicators. The graph (fig. 2) shows that following its basic function as a workshop-conference centre, utilisation grows or decreases in characteristic periods and 2003 was marked by a greater tourist activity between April and June, as well as in October and December (fig. 2) and in these months the seasonality exceeded the average of 100. The high indicator value in December was connected to other events organized by the KWB Bełchatow S.A., such as Barbórka (Miners' Day) or Karczma Piwna (Beer Festival) and Comber Babski. A decreased seasonality was easily seen in July with $52.2 \%$ in 1999 and $55 \%$ in 2003. The above 
cu, w 1999 r. wynosił 52,2\%, a w 2003 r. 55\%. Sytuacja taka spowodowana jest faktem, że „Sport Hotel" obsługuje gości przybywających głównie na konferencje lub osoby będące w podróży służbowej. Niższe wykorzystanie obiektu zanotowano również w miesiącach, w których przypadają święta. Wskaźnik przeciętnej liczby udzielonych noclegów na przełomie lat 2002 i 2003 wyniósł 18\%, przy niespełna $25 \%$ wykorzystania pokoi. Wskaźniki wykorzystania obiektu noclegowego wskazują na duże rezerwy w wykorzystaniu potencjału hotelowego.

Z noclegów w "Sport Hotelu” korzystali zarówno Polacy, jak i cudzoziemcy. W badanym czasie obiekt odwiedziły 5533 osoby, z czego turyści krajowi stanowili $87 \%$. Na podstawie zebranej dokumentacji dokonano charakterystyki oddzielnej dla firm i dla osób przyjeżdżających do hotelu. Najliczniejszą grupę gości stanowili klienci zbiorowi, których odnotowano 4530 ( $82 \%$ ogółu gości) z 417 firm wspólpracujących ze „Sport Hotelem” na przełomie 2002 i 2003 r. Osób indywidualnie odwiedzających hotel było tylko 1003 . W przypadku gości przybywających w grupach nie odnotowano danych dotyczących miejsca zamieszkania 3324 osób, co stanowi $60 \%$ ogólnej liczby gości hotelowych. Indywidualni goście obiektu to osoby przybywające do Bełchatowa $w$ interesach bądź będące $w$ nim przejazdem. Turyści krajowi korzystający w tym czasie z noclegów w „Sport Hotelu” pochodzili ze wszystkich województw Polski. Najliczniej reprezentowani byli mieszkańcy województwa mazowieckiego, którzy stanowili 18\% ogółu nocujących. Wysokie udziały mieli również mieszkańcy pięciu innych silnie zurbanizowanych województw: dolnośląskiego $(10 \%)$, śląskiego $(8 \%)$, wielkopolskiego $(7 \%)$, pomorskiego i łódzkiego (po 6\%). Z wymienionych województw pochodziła przeszło połowa $(54 \%)$ krajowych gości nocujących w „Sport Hotelu”. Najliczniejszą grupę stanowili mieszkańcy Warszawy $11 \%$ ogółu nocujących gości indywidualnych. Turyści pochodzili ze 129 miejscowości. Najwięcej, poza Warszawa, przyjechało z następujących miast: Wrocławia (5\%), Poznania, Łodzi i Gdyni (po 3\%) oraz Krakowa (2\%). Stosunkowo niewiele osób pochodziło z województw: lubuskiego, opolskiego, podkarpackiego, podlaskiego, świętokrzyskiego i warmińsko-mazurskiego, na które przypadło łącznie $7 \%$ ogółu gości krajowych nocujących w tym obiekcie w badanym czasie (rys. 3). W przypadku grupy gości indywidualnych nie odnotowano danych dla 267 osób, co stanowi 27\% ogółu turystów krajowych. situation results from the fact that the Sport Hotel serves guests arriving mainly at conferences or business travellers and utilisation was lower during holiday months. The average number of beds sold in 2003 came to $18 \%$, with nearly $25 \%$ of rooms used, pointing to large reserves of unused hotel potential.

Hotel beds at the Sport Hotel were bought by both Poles and foreigners. During the time of the study the hotel was visited by 5533 tourists, $87 \%$ of whom were Polish. On the basis of the collected data, the author prepared separate descriptions of companies and individual hotel guests. The majority were group clients, $4530 \quad(82 \%)$ from the 417 companies making use of the Sport Hotel in 2003. As far as individual guests were concerned, only 1003 were registered while in the case of group guests there was no data available regarding the addresses of 3324 (60\% of the overall number). Individual guests arrived on business or were travelling through Bełchatow to another destination. Polish tourists came from all the wojewordztwos in Poland with the most coming from the Mazowieckie Województwo, constituting $18 \%$ of tourists staying at the hotel. They were followed by the inhabitants of five other strongly urbanized Województwos: Dolnośląskie (10\%), Ślaskie (8\%), Wielkopolskie (7\%), Pomorskie $(6 \%)$ and Łódzkie (6\%). Over half (54\%) of Polish guests came from the województwos mentioned above with most arriving from Warsaw (11\%). Tourists came from 129 different places and, following Warsaw, the majority were from Wroclaw (5\%), Poznañ, Łódź and Gdynia (3\% each) and Kraków (2\%). Relatively few came from: Lubuskie, Opolskie, Podkarpackie, Podlaskie, Świętokrzyskie and Warmińsko-Mazurskie Województwos (7\%) (fig. 3). In the case of individual guests, data was not collected from 267, 27\% of all Polish tourists at the hotel. 


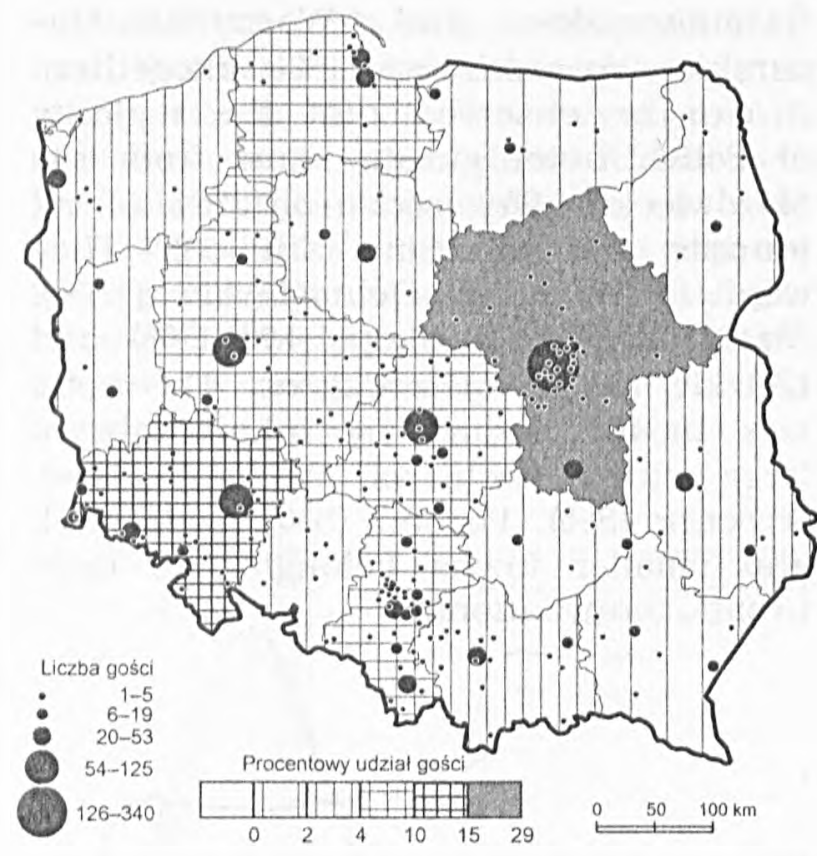

Rys. 3. Miejsca zamieszkania gości krajowych przebywających W "Sport Hotelu" w Betchatowie w 2003 r.

Najliczniejszą grupę korzystających z hotelu stanowili goście zbiorowi. Z 417 zarejestrowanych przedsiębiorstw, które nawiązaly kontakt $\mathrm{z}$ hotelem, gościło tu 4530 osób, co stanowi 82\% wszystkich przebywających gości. Najwięcej firm współpracujących z badanym obiektem miało siedzibę w województwie mazowieckim - 34\% ogólu wszystkich zakladów, w tym w samej Warszawie 30\% firm. W dalszej kolejności wymienić należy województwa: lódzkie $(12 \%)$, wielkopolskie $(9 \%)$ i dolnośląskie $(9 \%)$. Najwięcej firm wspóldzialających z hotelem ma swoją siedzibę w głównych miastach tych województw: Wrocław - 6\% ogółu firm, Poznań 5\%, Łódź i Gdańsk - po 3\% (rys. 4). Najmniej przedsiębiorstw, które wspólpracowaly z hotelem, pochodzilo z województw: kujawsko-pomorskiego, lubelskiego, lubuskiego, opolskiego, podkarpackiego, podlaskiego, warmińsko-mazurskiego oraz zachodniopomorskiego, łącznie stanowiły $11 \%$ wszystkich firm. Wśród osób, które przybyły w grupach, tylko w odniesieniu do 1006 odnotowano dane dotyczące miejsca ich zamieszkania. Stanowi to $22 \%$ wszystkich gości z 417 firm. Tak jak w przypadku gości indywidualnych oraz przedsiębiorstw, najliczniej reprezentowani byli mieszkańcy Warszawy (30\%). Goście „Sport Hotelu” przybyli lącznie ze 184 miejscowości, w tym najwięcej, poza Warszawa, pochodziło z Wroclawia (10\%), Poznania i Łodzi (po 6\%) oraz Gdańska i Krakowa (po 4\%). Goście krajowi, korzystający w tym czasie z noclegów

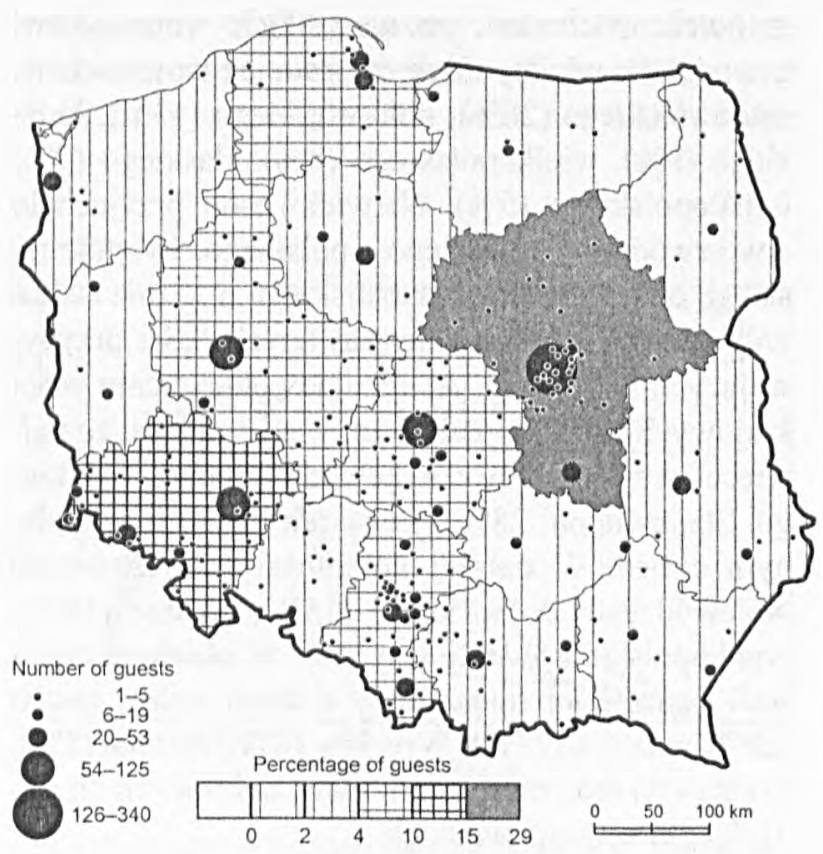

Fig. 3. Home locations of Polish guests staying at the Sport Hotel in Bełchatów in 2003

The most numerous were group guests. There were 4,530 from 417 companies ( $82 \%$ of all hotel guests). The majority of the companies were based in the Mazowieckie Województwo $34 \%, 30 \%$ of which came from Warsaw alone. They were followed by companies based in the Łodzkie (12\%), Wielkopolskie $(9 \%)$ and Dolnoślaskie (9\%) Województwos. The majority are based in their capitals: Wrocław - 6\%, Poznań 5\%, Łódź and Gdańsk - 3\% each (fig. 4). The fewest were from Kujawsko-Pomorskie, Lubelskie, Lubuskie, Opolskie, Podkarpackie, Podlaskie, Warminsko-Mazurskie and Zachodniopomorskie Województwos, constituting 11\%. Only 1006 group guests provided information on their home location - $22 \%$ of the overall number from 184 different places. Like individual guests, the majority came from Warsaw (30\%), followed by Wrocław (10\%), Poznań and Łódź (6\% each), as well as Gdańsk and Kraków (4\% each). Polish guests came from all województwos, mostly from Mazowieckie (28\%), Dolnośląskie (13\%), Łódzkie (8\%), Wielkopolskie (8\%), Śląskie $(7 \%)$ and Małopolskie (5\%). There were very few from Podlaskie, Opolskie, 
w hotelu pochodzili ze wszystkich województw, a najwyższe udzialy mieli mieszkańcy województw: mazowieckiego (28\%), dolnośląskiego (13\%), łódzkiego (8\%), wielkopolskiego (8\%), śląskiego (7\%) i małopolskiego $(5 \%)$. Niewiele osób przyjechało z województw podlaskiego, opolskiego, świętokrzyskiego oraz warmińsko-mazurskiego. Łącznie stanowily one $5 \%$ ogółu zarejestrowanych gości przybywających w grupach. Analizując pochodzenie gości krajowych „Sport Hotelu”, zauważyć można, że najwięcej przybyło ich z województwa mazowieckiego. Stanowią oni $28 \%$ wszystkich turystów w badanym czasie. W dalszej kolejności zarejestrowano województwa: dolnośląskie (15\%), śląskie $(10 \%)$, wielkopolskie i łódzkie (po 9\%). W obiekcie nocowali najczęściej mieszkańcy dużych miast, takich jak: Warszawa (21\%), Wrocław (8\%), Poznań (5\%), Łódź (4\%) oraz mniejszych miast należących do dużych aglomeracji miejskich.

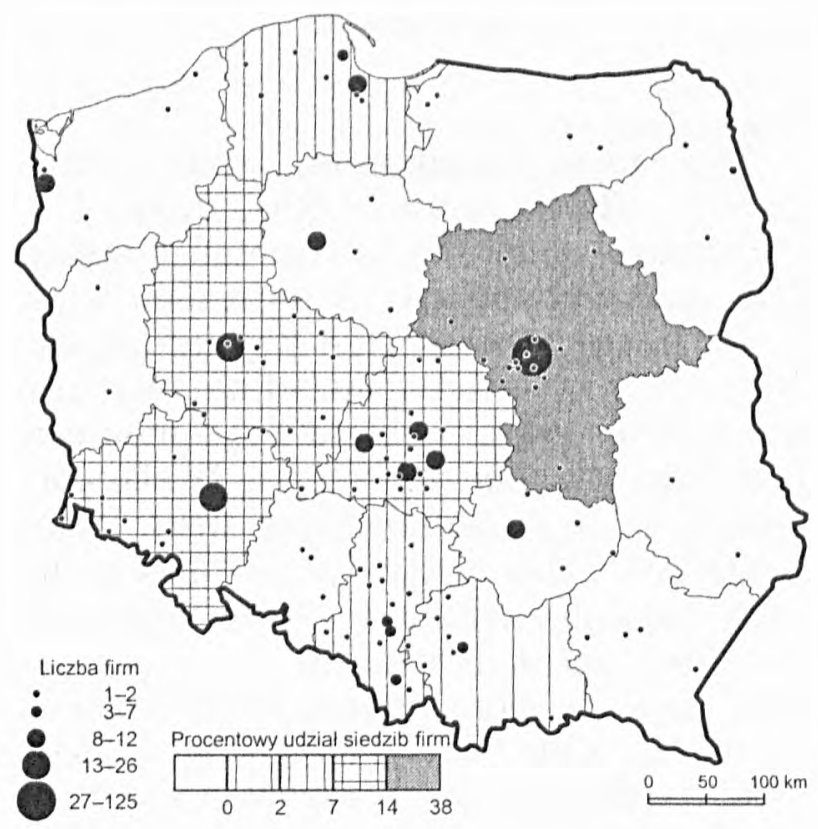

Rys. 4. Siedziby firm współpracujących ze „Sport Hotelem" w Bełchatowie w 2003 r.

W przypadku gości indywidualnych korzystających z noclegów na przełomie 2002 i 2003 r. prawie połowa $(47 \%$ ogólu) przyjechała do hotelu z odległości nie większej niż 200 km (rys. 5). Podobna sytuacja dotyczy firm i ich pracowników; $57 \%$ siedzib przedsiębiorstw współpracujących ze „Sport Hotelem” znajduje się w odległości 101$200 \mathrm{~km} \mathrm{i} \mathrm{w} \mathrm{takiej} \mathrm{samej} \mathrm{odległości} \mathrm{zamieszkuje}$ największa grupa osób w nich pracujących (54\%). Drugą grupę stanowią goście, którzy przybyli z odległości 201-300 km - 23\% wszystkich klientów
Świętokrzyskie and Warmińsko-Mazurskie Województwos (5\% altogether). It can be observed that the majority of Polish hotel guests came from the Mazowieckie Województwo (28\% of all tourists at the time studied). They were followed by Dolnoślaskie (15\%), Śląskie (10\%), Wielkopolskie (9\%) and Łódzkie (9\%) Województwos. The hotel was mostly visited by inhabitants of large cities such as Warsaw (21\%), Wrocław (8\%), Poznań (5\%), Łódź (4\%), and smaller towns belonging to large urban conurbations.

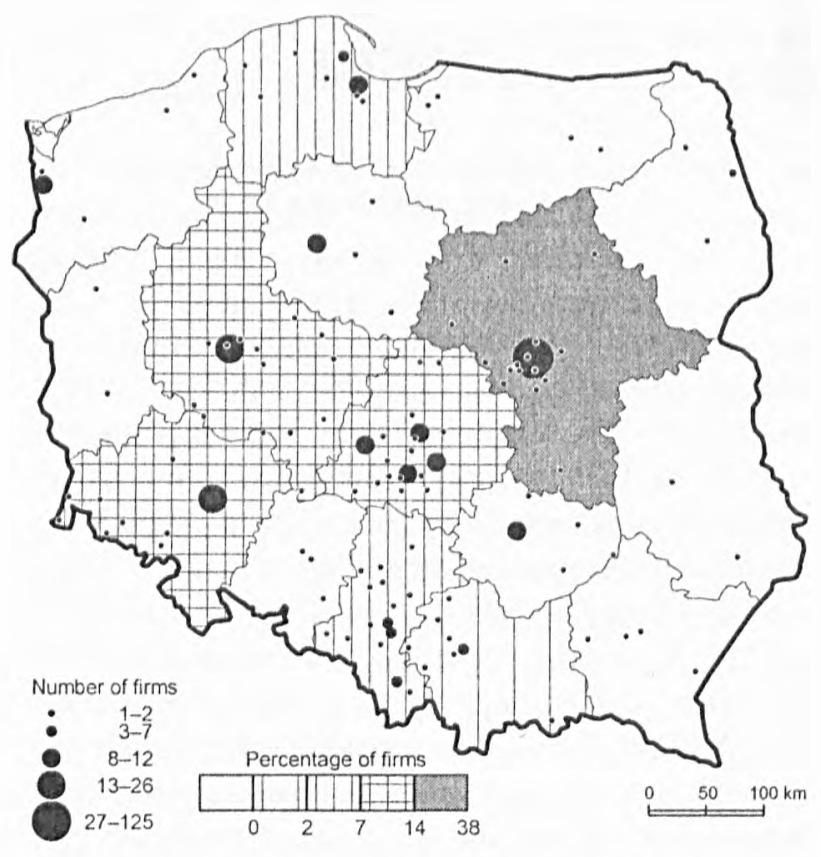

Fig. 4. Registered offices of companies utilising the Sport Hotel in Betchatów in 2003

In the case of individual guests in 2003, nearly half (47\%) travelled less than $200 \mathrm{~km}$ (fig. 5) and was similar to companies and their employees, where $57 \%$ are based between 101-200 km away, and $54 \%$ of their employees live within the same distance band. The second most numerous travelled between $201-300 \mathrm{~km}$ (23\% of all individual and $18 \%$ of all group guests). The majority of company registered offices are located within $300 \mathrm{~km}(87 \%)$, and the majority of their employees live between 101-400 km from the hotel $(85 \%)$. Individual tourists 
indywidualnych i $18 \%$ osób zatrudnionych w firmach. Najwięcej siedzib firm zlokalizowanych jest w odległości do $300 \mathrm{~km}$ (87\% wszystkich zakładów), natomiast największy odsetek ich pracowników zamieszkuje obszary oddalone od hotelu o 101-400 km (85\% osób). Najmniejszą grupe stanowią goście indywidualni zamieszkali w odległości powyżej $400 \mathrm{~km}$ i podobna sytuacja została odnotowana w odniesieniu do siedzib firm $(6 \%$ wszystkich) oraz ich pracowników (4,1\%).

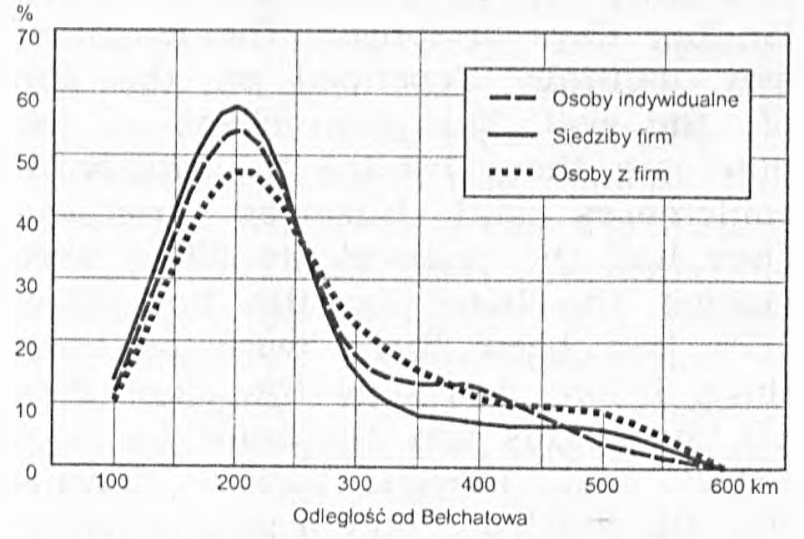

Rys. 5. Goście krajowi „Sport Hotelu” w Bełchatowie na przełomie lat 2002 $\lceil 2003$ wg odległości od miejsca zamieszkania

Nocujący w badanym obiekcie obcokrajowcy pochodzący $\mathrm{z}$ różnych krajów świata stanowili 13\% ogółu gości, z czego 96\% przyjechało z Europy. Spośród obywateli krajów Europy Zachodniej wizytowało obiekt najwięcej Niemców (36\%) i Francuzów $(9,4 \%)$. Duży udział gości pochodzenia niemieckiego można wytlumaczyć współpracą KWB Bełchatów z niemieckimi specjalistami ds. modernizacji maszyn, które unowocześniane sa według niemieckiej technologii. Dość wysoki odsetek Francuzów pośród gości hotelowych mógl być spowodowany budową francuskiego supermarketu w bliskim sąsiedztwie hotelu. Z krajów ościennych najliczniejszą grupę stanowili Białorusini $(6 \%)$, Rosjanie $(5,6 \%)$ i Czesi $(4,4 \%)$. Na pozostałe kraje Europy przypada łącznie $17 \%$ gości, w tym z Portugalii 5,1\%, Finlandii $4 \%$, Włoch $3,5 \%$ oraz z Holandii i Austrii po 3\%. Spośród obywateli pozostałych kontynentów, którzy nocowali w badanym obiekcie, odnotowano Australijczyków, Chińczyków oraz Kolumbijczyków. Stanowili oni 1,1\% wszystkich gości. Udział turystów z Ameryki Północnej wyniósł łącznie 2,6\%. Uogólniając przytoczone dane można stwierdzić, że wśród obcokrajowców nocujących w „Sport Hotelu" w Bełchatowie najliczniej reprezentowani living over $400 \mathrm{~km}$ away were the fewest, and company registered offices (6\%) and their employees $(4.1 \%)$ were similarly low.

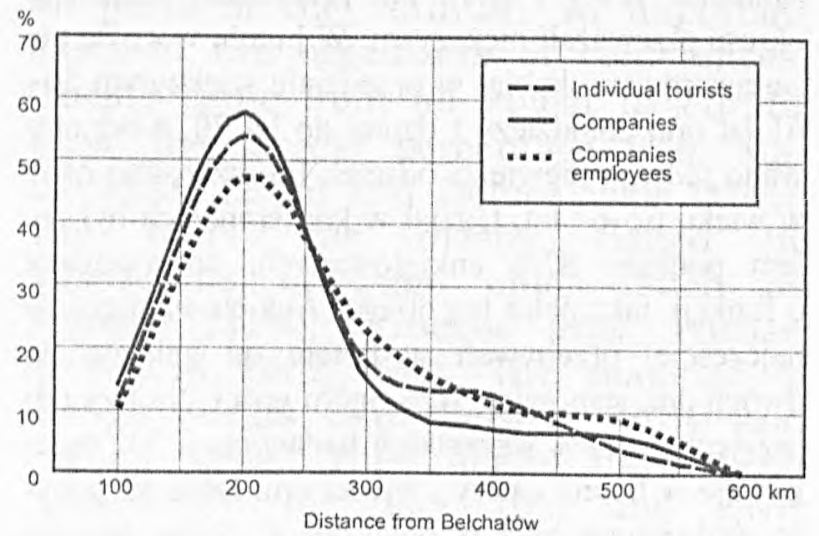

Fig. 5. Polish guests of the Sport Hotel in Betchatów in 2003, according to distance from home location

Foreign guests constituted $13 \%$ of the overall number and $96 \%$ were from Europe. The majority came from Germany (36\%), and then France $(9.4 \%)$. The large percentage of Germans resulted from collaboration between KWB Bełchatów and German specialists on machine modernization using German technology. The relatively high percentage of French guests may have resulted from the fact that a French supermarket was being built near to the hotel at that time. Other foreign guests included citizens of Belarus (6\%), Russia (5.6\%), Portugal (5.1\%), the Czech Republic (4.4\%), Finland $(4 \%)$, Italy $(3.5 \%)$, the Netherlands $(3 \%)$ and Austria (3\%). The remaining 17\% of European guests arrived from other countries. As far as visitors from other continents were concerned, citizens of Australia, China and Colombia were recorded constituting $1.1 \%$ of all guests while the percentage from North America was 2.6\%. Summing up, the majority of foreigners staying at the Sport Hotel in Bełchatow were from neighbouring countries and Western Europe.

A typical guest staying at the hotel is 26-31 years old, with a university 
byli obywatele państw ościennych i Europy Zachodniej.

Typowy gość hotelowy zatrzymujący się w „Sport Hotelu" to osoba w przedziale wiekowym 26-31 lat, z wyksztalceniem wyższym $(76 \%)$ i zatrudniona w zakładzie pracy $(74 \%)$. Na przestrzeni badanego okresu przeważali mężczyźni. W hotelu w ogóle nie zarejestrowano kobiet w przedziale wiekowym 5661 lat oraz młodzieży i dzieci do lat 20, a odnotowano jedynie niewielki odsetek (poniżej 4\%) osób w wieku 62-67 lat. Udział w konferencjach był celem podróży $87 \%$ ankietowanych, co świadczy o funkcji, jaką pełni ten obiekt. Ankietowani goście najczesściej przebywali w hotelu od jednego do dwóch dni, stanowiąc 76\% ogółu gości. Na trzy dni przyjechało $18 \%$ wszystkich badanych, a $5 \%$ przebywało w hotelu cztery i więcej dni. Dlugość pobytu uzależniona była oczywiście od celów wizyty. Głównymi klientami obiektu są osoby przyjeżdżające na szkolenia, narady i konferencje, a także na spotkania biznesowe. Ponad połowa ankietowanych $(66 \%)$ była w hotelu po raz pierwszy, $16 \%$ odwiedziło obiekt dwa-trzy razy, a zaledwie 3\% powyżej 10 razy. Sytuacja taka występuje zarówno wśród gości krajowych, jak i zagranicznych, z czego wynika, że „Sport Hotel”, ma tylko niewielką grupę stalych gości.

\section{PODSUMOWANIE}

Praca poświęcona jest charakterystyce funkcjonowania trzygwiazdkowego obiektu noclegowego „Sport Hotel” Sp. z o.o. w Bełchatowie, w której wszystkie udziały posiada KWB „Bełchatów” SA. Wyniki przeprowadzonych badań pozwalaja stwierdzić, że jest to obiekt typowo konferencyjny, co potwierdza m.in. fakt, iż najliczniejszą grupę korzystającą z obiektu stanowią klienci zbiorowi ( $82 \%$ ogółu nocujących w badanym czasie). Typowym gościem hotelowym jest osoba w wieku produkcyjnym $z$ wykształceniem wyższym $(76 \%)$ i zatrudniona w zakładzie pracy (74\%). Konferencje były celem podróży $87 \%$ ankietowanych, wobec czego średnia dlugość pobytu gościa hotelowego wynosiła 1,57 dnia. Wykorzystanie obiektu jest typowo sezonowe, co potwierdzają obliczenia dotyczące sezonowości oraz wykorzystania pokoi. Największe obłożenie hotelu odnotowano w maju i październiku (po 20\%), a lipiec i sierpień (łącznie $9 \%$ ) był okresem pozasezonowym. Niższe wykorzystanie notuje się również w miesiącach, w których przypadają święta. Na podstawie anali- degree (76\%) and employed (74\%). At the time of study male guests were in a majority. The hotel records do not include women aged 56-61 or under 20. There are records of a small percentage (under 4\%) of guests aged 62-67. For $87 \%$ of respondents the aim of travel was participation in conferences, confirming the main function of the hotel, usually staying for one or two days (67\%). A three-day stay was mentioned by $18 \%$, and $5 \%$ remained for four days or longer. The length of stay naturally depended on the aim of the visit. The main clients of the hotel are those coming to workshops, conferences and business meetings. Over half the respondents (66\%) were visiting the hotel for the first time, $16 \%$ had been there twice or three times before, but only $3 \%$ more than 10 times. This was the same for both Polish and foreign guests showing that the hotel has only a small number of regular guests.

\section{CONCLUSIONS}

The article is devoted to the three-star Sport Hotel in Belchatow all of whose shares are owned by KWB Belchatow S.A. The results of the research show that it is a typical conference hotel where the majority of guests are group clients ( $82 \%$ at the time of the study). A typical hotel guest is a person of working age, with a university degree (76\%) and employed $(74 \%) .87 \%$ of the respondents pointed to a conference as the aim of their stay; the average length was 1.57 days. The hotel utilisation is typically seasonal, which can be seen in the seasonality and room utilisation figures. The highest were noted in May and October (20\% in each), while July and August (jointly 9\%) were the out-of-season months. Lower utilisation is also recorded during public holidays. It appears that the most intensive tourist activity within a week occurs on Monday, Wednesday and Thursday and a considerably lower activity was 
zy zebranego materiału, okazuje się, że największe natężenie ruchu w ciągu tygodnia występuje w poniedziałek, środę i czwartek. Zdecydowanie mniejsze odnotowano w sobotę i niedzielę $(10 \%$ ogółu nocujących). „Sport Hotel” obsługuje zarówno gości krajowych (87\%), jak i zagranicznych (13\%). Jego usytuowanie w Belchatowie (centrum Polski), dogodny dojazd ze wszystkich stron kraju, stanowi ważny atut dla organizatorów różnych konferencji. Osoby nocujące w tym hotelu pochodzily ze wszystkich województw. W przypadku gości krajowych największy udział miały osoby z województwa mazowieckiego, które stanowiły $28 \%$ wszystkich gości, i województwa dolnośląskiego $-15 \%$. W obiekcie tym najczęściej nocowali mieszkańcy dużych miast, takich jak: Warszawa (21\%), Wrocław (8\%), Poznań (5\%) i Łódź (4\%). Spośród obcokrajowców najliczniej reprezentowani byli Niemcy (36\%) i Francuzi (9\%). Mogło to być spowodowane faktem, że KWB „Bełchatów” współpracuje z niemieckimi specjalistami ds. modernizacji maszyn, jak również że w bełchatowsko-kleszczowskiej strefie uprzemysłowionej działają przedsiębiorstwa z kapitalem zagranicznym, m.in.: niemieckim, francuskim, austriackim i portugalskim. Spośród najliczniej odwiedzających hotel przedstawicieli firm na przelomie lat 2002 i 2003 wymienić należy: Pliva Kraków, Syngenta Crop Protection Sp. z o. o., Perfetti Van Melle, Euro-Zoo Sp. z o.o. oraz Commercial Union Polska Sp. z o.o. Są to głównie firmy promujące produkty zagraniczne na rynku polskim. Pozostałą część klientów stanowią osoby przybyłe indywidualnie, goszczące w Bełchatowie w interesach bądź będące przejazdem. Belchatów jest ważnym ośrodkiem ponadregionalnym ze względu na znajdujący się tu Zespół Górniczo-Energetyczny. Miasto ma dobre warunki dla lokalizacji nowych przedsiębiorstw oraz duże rezerwy terenów i powierzchni przemysłowych. Strefa przemysłowa znajdująca się w Rogowcu koło Bełchatowa przyciąga wielu inwestorów nie tylko z całej Polski, ale i z Europy, dzięki czemu rosną szanse liczniejszego i bardziej częstego korzystania z usług „Sport Hotelu”.

Wskaźniki obłożenia ukazują duże rezerwy w wykorzystaniu potencjału hotelowego. Wielkość ruchu turystycznego zarejestrowanego $\mathrm{W}$ tym obiekcie w 2003 r. zmniejszyła się o 14\% w stosunku do roku 1999, w którym poziom wykorzystania pokoi sięgal 39\%, natomiast w 2003 r. spadł do $25 \%$. Niski wskaźnik wykorzystania pokoi wynika z małej atrakcyjności turystycznej miasta, observed on Saturday and Sunday (10\% of the total). The Sport Hotel serves both Polish (87\%) and foreign (13\%) guests.

The hotel is in Belchatow, in the centre of Poland, convenient for travellers from all parts of the country, an important asset to the organizers of conferences. Guests came from all Polish województwos, the largest percentage from Mazowieckie $(28 \%)$ and Dolnośląskie (15\%). The hotel was mostly visited by inhabitants of large cities, such as Warsaw (21\%), Wroclaw (8\%), Poznań (5\%) and Łódź (4\%). The majority of foreign guests were German (36\%) and French (9\%). This might have been caused by the fact that the KWB Bełchatów collaborates with German specialists on machine modernization, as well as the Bełchatów-Kleszczów industrial zone having many enterprises based on foreign capital (German, French, Austrian and Portuguese). Among the companies whose representatives stayed at the hotel in 2003, Pliva Krakow, Syngenta Crop Protection Ltd., Perfetti Van Melle, Euro-Zoo Ltd., and Commercial Union Poland Ltd should be mentioned, companies promoting foreign products on the Polish market. The remaining guests arrived individually, on business or en route to another destination. Bełchatow is an important regional centre due to its Mining-Power Engineering Complex and the city offers good conditions for establishing new enterprises and has large reserves of industrial land. The industrial zone in Rogowiec near Bełchatów attracts many investors not only from Poland but from the whole of Europe. Due to this, chances of a more intensive utilisation of the services offered by the Sport Hotel are growing.

Utilisation figures point to large unused reserves of hotel potential. Tourist activity registered there in 2003 had decreased by $14 \%$ compared to 1999 , when room take-up reached $39 \%$ - in 2003 it had dropped to $25 \%$. The low room take-up results from the low tourist attractiveness of the town, lack of professional advertising, and above all from the 
braku profesjonalnej reklamy, ale przede wszystkim z faktu, że „Sport Hotel” nie prowadzi systematycznej analizy rynku. Wysoki spadek obłożenia spowodowal osłabienie kondycji ekonomicznej obiektu i jedynie to, że obiekt jest wlasnością KWB Bełchatów SA, która dofinansowuje hotel, ciągle umożliwia jego funkcjonowanie.

\section{PRZYPIS}

\footnotetext{
${ }^{1}$ Artykul powstał na podstawie pracy magisterskiej wykonanej przez autorkę na seminarium $\mathrm{z}$ geografii turyzmu i hotelarstwa w Uniwersytecie Lódzkim w 2004 r.; promotorem pracy byl prof. S. Liszewski.

${ }^{2}$ Wykorzystano m.in. następujące wskaźniki ilościowe:
}

$W_{p}=\frac{L_{w p}}{L_{p} \cdot T_{w}}, \quad P_{d}=L_{n} \mid L_{k e}, \quad W_{s}=\left(L_{t m} \mid L_{\mathrm{s} r} r\right) \cdot 100$

gdzie: $W_{p}$-stopień wykorzystania pokoi, $L_{w p}$ - liczba wykorzystanych pokoi w danym okresie, $L_{p}$ - liczba pokoi obiektu noclegowego $w$ danym okresie, $T_{w}$ - czas eksploatacji $w$ danym okresie, $P_{d}$ - wskaźnik przeciętnej długości pobytu gościa w hotelu, $L_{n}$ - rozmiary świadczonych usług, $L_{k c}$ - liczba gości, $W_{s}$ - wskaźnik sezonowości, $L_{t m}$ - liczba turystów w kolejnym miesiącu, $L_{\text {srtr }}$ - średnia miesięczna liczba turystów z 1999 oraz z przełomu lat 2002 i 2003. fact that the Sport Hotel's management do not carry out a systematic market analysis. The serious decrease in utilisation has led to the hotel's weak economic condition and only the fact that it is the property of KWB Belchatow SA, which subsidizes it, enables it to survive.

\section{FOOTNOTES}

1 The article is based on the MA thesis written by the author at the Geography of Tourism and Hotel Management seminar, University of Lódź in 2004, under the supervision of Prof. Liszewski.

2 The following quantitative indicators were used:

$$
W_{p}=\frac{L_{w p}}{L_{p} \cdot T_{w}}, \quad P_{d}=L_{n} \mid L_{k e}, \quad W_{s}=\left(L_{t m} \mid L_{\mathrm{s} r t r}\right) \cdot 100
$$

where: $W_{p}$ - room utilisation, $L_{\text {cop }}$ - number of rooms used in a given period, $L_{p}$ - number of hotel rooms in a given period, $T_{w}$ - time of utilisation in a given period, $P_{d}$ - guest's average length of stay, $L_{n}$ - scope of service, $L_{k e}$ - number of guests, $W_{s}$ - seasonality quotient, $L_{t m}$ - number of tourists in the following month, $L_{\text {sitr }}$ - average monthly number of tourists in 1999 and 2003.

\section{BIBLIOGRAFIA - BIBLIOGRAPHY}

LISZEWSKI S. (red.), 1985, Zmiany $w$ środowisku przyszłego Betchatowskiego Okręgu Przemystowego, PWN, Warszawa, Łódż, s. 21-36.
RapaCz A., 1994, Przedsiębiorstwo turystyczne. Podstawy i zasady działania, PWN, Warszawa, s. 121-143.

TURKOWski M., 1993, Hotelarstwo-elementy marketingu, PWE, Warszawa, s. 21-24. 